\title{
O Grande Teatro: Uma Nova Perspectiva sobre os Processos de Construção Nacional na América Latina
}

\author{
Matías Almeida Garzón \\ Orientador: Pfr. Dr. José Alves de Freitas Neto
}

\section{Resumo}

O presente trabalho visa à realização de uma revisão do processo de conformação dos que viriam a ser os futuros Estados Nacionais latino-americanos, especificamente sobre a experiência da Grã-Colômbia nos anos referentes ao período da independência contra a coroa espanhola, a conformação do Estado-Nação e a sua iminente separação.

\section{Palavras-chave:}

História Latino-americana, Construção Nacional, Teorías de Estado

\section{Introdução}

$\mathrm{Na}$ atualidade, o conceito de Nação se apresenta completamente naturalizado na mente dos indivíduos, uma verdade absoluta.

O presente trabalho monográfico não só se propõe em realizar uma tentativa por estudar os elementos da Nação dentro da sociedade contemporânea e do ser humano, mas também conseguir entender o processo de mecanismos que deram fruto à naturalização temporal do mesmo: A minha proposta é a de destrinchar o conceito naturalizado da Nação.

Partindo de tal pressuposto, o trabalho foi dividido em três capítulos respectivos. O primeiro vai se focar no estudo dos aparelhos constitucionais presentes em dois documentos específicos, o segundo sobre as causalidades do fracasso da associação entre os corpos autônomos, remanescentes do período colonial enfatizando a frágil atmosfera política existente na época, isto mediante a análise da imprensa. $O$ último ponto preocupa-se com uma breve contextualização do fracasso da união sonhada por Simón Bolívar, desdobrando-se nos novos processos de construção nacional que os territórios remanescentes da união grã-colombiana vão ter que afrontar.

\section{Resultados e Discussão}

O eixo teórico da pesquisa se vê representada por diversas obras, mas em particular pela do intelectual argentino Elias Palti, cujo trabalho lida diretamente com a questão da desconstrução antigenealógica do discurso nacional. Esse tipo de leitura consegue revelar os diversos mecanismos discursivos que terminam por consolidar a ideia de uma nação, um plural comum para um corpo social.

O caso da Grã-Colômbia é tão interessante, porque consegue apresentar as diversas tentativas por criar esta ilusão, de certo modo pode ser visto à maneira de laboratório da nação. A presente pesquisa analisa as diversas componentes que tomaram partido nos embates dentro da jovem nação latino-americana. Elementos discursivos, jurídicos e jornalísticos.

Como produto da pesquisa, múltiplas questões podem ser levantadas, é possível evidenciar permanências de estruturas sociais coloniais ainda presentes na sociedade pós independência. Essas mesmas possuíram um peso e influência tão relevante, que terminaram por impossibilitar a criação do singular coletivo. Uma clara oposição entre os campos dogmático e prático se demonstra imperante, os esforços políticodiscursivos do governo não conseguiram alterar as raízes socioeconômicas, herança do período colonial o que termina por debilitar ainda mais o fraco corpo político, encaminhando-o para a separação e o fim do efêmero Estado Sul-americano.

Figura 1. Mapa da Grã-Colômbia

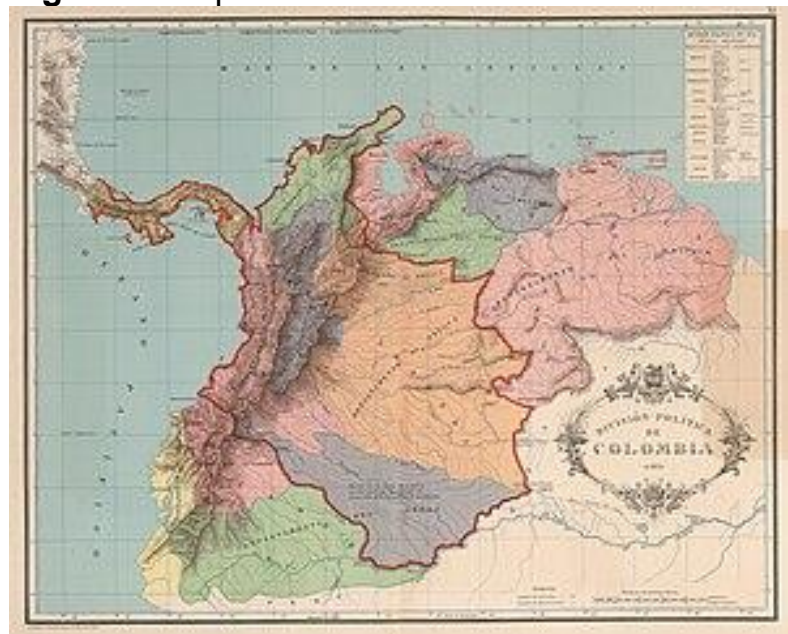

\section{Conclusões}

Sendo uma característica importante de ressaltar dentro do contexto, o maior desafio no momento de empreender uma pesquisa na presente temática pode ser conseguir entender a situação latino-americana a partir das conjunturas específicas dela mesma, situação na qual a transposição de ideias se apresenta como um claro fator, pois possui efeitos consideráveis na elaboração e consolidação das narrativas históricas.

É importante levar em conta natureza global do mundo em que vivemos, mas na hora de estudar casos específicos é igualmente relevante levar em consideração as caraterísticas próprias do mesmo como também a forma de como são lidas e reinterpretadas as diversas vertentes de pensamento. Esses embates de categoria teórico-conceitual terminam por criar absolutos reais dentro da sociedade humana. O Estado Nação sendo um magnifico exemplo disto. 